\title{
Inventário da realidade: fazeres, saberes e sujeitos campesinos em prosas e rimas
}

\author{
Reality inventory: peasants knowledge, knowledge and subjects in prose and \\ rhymes \\ Sérgio Luiz Teixeira
}

Resumo:O presente artigo pretende socializar o trabalho investigativo coletivo, dialético, dialógico e práxico da escola inserida no Assentamento Contagem - Distrito Federal - Brasil, intitulado Escola Classe Sonhém de Cima: os saberes e os fazeres do campo com prosas e rimas com o objetivo principal de ressignificar a identidade da escola do campo, a partir da materialização da construção do inventário social, histórico cultural e ambiental. Os objetivos específicos: conhecer a história da constituição do Assentamento Contagem, com a chegada dos posseiros e dos Sem Terra na ocupação da fazenda devoluta até a conquista da terra e reconhecer a cultura camponesa, em especial, os modos de produção de vida na terra para produzir alimentos e o orgulho de serem camponeses. As ações pedagógicas foram: trabalho com os eixos terra, direito, trabalho e alimento; visita aos espaços comunitários e familiares (galpão, padaria, casa de farinha, lavouras e residências) com a mediação dos camponeses/as; roda de conversa com os/as assentados/as e com agentes comunitários; análise de fotos do livro Terra de Sebastião Salgado; interpretação de poemas de Cora Coralina e Pedro Munhoz; construção de estandartes; apresentação da encenação teatral A contagem do Contagem. O registro das ações teve fotos, vídeos, textos e desenhos produzidos pelo Coletivo Girassol. O trabalho investigativo contribuiu na aprendizagem dos educandos: conheceram a luta, a persistência e a resistência dos sujeitos históricos camponeses, que conquistaram a terra para morar, trabalhar e produzir alimentos e compreenderam a importância da terra para a constituição da identidade dos povos camponeses.

Palavra-chaves: escola, inventário da realidade e identidade camponesa.

Abstract:The present article intends to socialize the collective, dialectical, dialogical and praxic investigative work of the school inserted in the Contagem Settlement - Federal District - Brazil, entitled Escola Classe Sonhém de Cima: the knowledge and actions of the field with prose and rhymes with the main objective of resignify the identity of the rural school, based on the materialization of the construction of the social, historical, cultural and environmental inventory. The specific objectives: to know the history of the establishment of the Contagem Settlement, with the arrival of the squatters and the Landless in the occupation of the vacant farm until the conquest of the land and to recognize the peasant culture, in particular, the ways of life production on the land for produce food and the pride of being peasants. The pedagogical actions were: work with the land, law, work and food axes; visit to community and family spaces (shed, bakery, flour house, crops and homes) with the mediation of peasants; conversation with settlers and community agents; analysis of photos from the book Terra by Sebastião Salgado; interpretation of poems by Cora Coralina and Pedro Munhoz; construction of standards; presentation of the theatrical performance The Count of Contagem. The registration of the actions had photos, videos, texts and drawings produced by Coletivo Girassol. The investigative work contributed to the students' learning: they knew the struggle, the persistence and the resistance of the historical peasant subjects, who conquered the land to live, work and produce food and understood the importance of the land for the constitution of the identity of the peasant peoples.

Keywords: school, reality inventory and peasant identity. 


\section{Introdução}

Eu quero uma escola do campo/Que tenha a ver com a vida com a gente

Querida e organizada/E conduzida coletivamente. (Gilvan dos Santos)

O presente artigo tem o objetivo em registrar e compartilhar a síntese das ações pedagógicas da pesquisa etnográfica desenvolvidas pelos educandos e educandas com mediação dos educadores e educadoras da Escola Classe Sonhém de Cima, inserida no território educativo camponês, o Assentamento Contagem, na Região Administrativa da Fercal, do Distrito Federal, Brasil.

As matrizes formativas presentes no território camponês, a Terra, Direitos Humanos, Trabalho, História, Cultura, Conhecimento Popular e Organização Coletiva foram escolhidas como eixos balizadores para subsidiar a práxis pedagógica, intitulada Escola Classe Sonhém de Cima: os saberes e os fazeres do campo com prosas e rimas, com o propósito de promover a interação dialética dos saberes e dos fazeres da população camponesa com os conhecimentos curriculares. E concomitantemente, desenvolveu a materialização da construção do inventário da realidade nos aspectos sociais, históricos, culturais e ambientais para contribuir com o processo de ressignificação da identidade escola na perspectiva epistemológica da Educação do Campo.

Os objetivos formativos que permearam a pesquisa na perspectiva da práxis pedagógica foram: conhecer a história da constituição do Assentamento Contagem, desde a chegada dos primeiros posseiros e dos Sem Terra no processo de ocupação da fazenda devoluta até a conquista da chácara para cada família e reconhecer a cultura camponesa, em especial, os modos de produção de vida, em especial, as formas de trabalho na terra (agricultura e pecuária) para produzir alimentos e recursos financeiros, possibilitando a presença e permanência das famílias no território camponês com dignidade e com orgulho de serem camponeses.

As estratégias desenvolvidas foram as seguintes: a) visita às famílias camponesas nas residências e locais de trabalho (padarias e lavouras); b) entrevistas e roda de conversas com as famílias camponesas e agentes comunitários; c) visitas ao prédio escolar antigo e galpão da comunidade; d) observar as fontes naturais (rios, fauna e flora) do território; e) registro de fotos 
e vídeos dos sujeitos e da realidade encontrada; d) produção de textos (memórias, poesias e contos) e de desenhos pelos estudantes; e) apresentação de encenação teatral, mística e sarau poético; f) análise dos dados gerados e exposição dos trabalhos para a comunidade escolar.

\section{Adentrando no território camponês}

Quando eu morrer/Que me enterrem na beira do chapadão/Contente com minha terra/Cansado de tanta guerra (Chico Buarque)

O Assentamento Contagem localiza-se na rodovia DF 205 Leste. Está aproximadamente uns $18 \mathrm{~km}$ distantes da Região Administrativa da Fercal e do Plano Piloto, Brasília, aproximadamente $54 \mathrm{~km}$ de distância. No aspecto geográfico, o território do Assentamento está inserido na Área de Proteção Ambiental (APA) do Planalto Central e da Bacia Hidrográfica do Rio Maranhão.

Adentrar no território camponês, no qual a escola está presente, é importante que os educadores e as educadoras desenvolvam um olhar investigativo e sensível, para compreender o meio no qual está permeando, pois é um espaço repleto de vida social e diversidade de cultura camponesa, como nos explica Fernandes (2012):

O território camponês é o espaço de vida do camponês. É o lugar ou os lugares onde uma diversidade de culturas camponesas constrói sua existência. O território camponês é uma unidade de produção familiar e local da residência da família, que muitas vezes pode ser constituída de mais de uma família. Esse território é predominantemente agropecuário, e contribui com a maior parte da produção de alimentos saudáveis, consumidos principalmente pelas populações urbanas. (FERNANDES,2012, p.744).

Nos meados dos anos 80 e início dos anos 90, a fazenda Maranhão, com 926 hectares, voltada à pecuária e mineração de areia as margens dos rios da região, foi considerada terras devolutas pelo Instituto Nacional de Colonização e Reforma Agrária (INCRA).

O processo de ocupação dessas terras, através da presença dos camponeses, iniciou com os alguns posseiros que vieram do Córrego do Ouro e de Sobradinho (Distrito Federal - Brasil). Mesmo com temor de serem expulsos 
por fiscais do INCRA, começaram a usar a terra plantando arroz, criando animais e aos poucos foram construindo suas moradias improvisadas.

No primeiro semestre do ano de 1993, na sede do INCRA, na capital do Estado de Goiás, os posseiros encontraram alguns representantes de um grupo de trabalhadores rurais sem-terra, acampados à beira de uma rodovia entre Planaltina-DF e Formosa-GO. Nesse encontro, que não foi planejado, os posseiros informaram aos Sem Terra sobre a existência e a situação irregular da fazenda e, com o aval do INCRA, consolidaram a parceria para iniciar legalmente o processo de territorialização das terras devolutas.

A prosa com João do Óculos, Itamar, Seu Caetano, Dona Roseli e Dona Nenê, representantes dos Sem Terra, possibilitou conhecer a história da ocupação do território camponês. Relembraram a chegada na fazenda Maranhão num dia chuvoso, na primavera do mesmo ano. Os caminhões com os poucos pertences das 45 famílias atolaram na estrada estreita para chegar no galpão do curral desativado na sede da fazenda. Chegaram e começaram a organizar o acampamento. Fernandes (2012) entende que o acampamento é um espaço de luta e resistência, além de ser um trabalho de base familiar preparativo para a ocupação da terra.

\begin{abstract}
Acampamento é um espaço de luta e resistência. É a materialização de uma ação coletiva que torna pública a intencionalidade de reivindicar o direito à terra para produção e moradia. O acampamento é uma manifestação permanente para pressionar os governos na realização da Reforma Agrária. Parte desses espaços de luta e resistência é resultado de ocupações de terra; outra parte, está se organizando para preparar a ocupação da terra. A formação do acampamento é fruto do trabalho de base, quando famílias organizadas em movimentos socioterritoriais se manifestam publicamente com a ocupação de um latifúndio. Com esse ato, as famílias demonstram sua intenção de enfrentar as difíceis condições nos barracos de lona preta, nas beiras das estradas; demonstram também que estão determinadas a mudar os rumos de suas vidas, para a conquista da terra, na construção do território camponês. (FERNANDES, 2012, p.21).
\end{abstract}

Não demorou nem dois anos, os acampados e os posseiros conquistaram o direito de morar e trabalhar na terra. Atualmente o Assentamento Contagem é constituído de aproximadamente de meia centena de famílias, que contribuíram e ainda estão contribuindo com a construção do território camponês, pois o 
trabalho familiar é a essência constituinte do território camponês, como enfatiza Fernandes (2012):

A unidade espacial se transforma em território camponês quando compreendermos que a relação social que constrói esse espaço é o trabalho familiar, associativo, comunitário, cooperativo, para o qual a reprodução da família e da comunidade é fundamental. A prática dessa relação social assegura a existência do território camponês, que por sua vez, promove a reprodução dessa relação social. Essas relações sociais e seus territórios são construídos e produzidos, mediante a resistência, por uma infinidade de culturas camponesas em todo o mundo, num processo de enfrentamento permanente com as relações capitalistas. (FERNANDES,2012, p.744)

Os assentados da Reforma Agrária reivindicaram do Estado e conseguiram os direitos sociais, como abastecimento de água, fornecimento de energia elétrica, construção da escola, atendimento de técnicos agrícolas para orientar nas atividades agropecuárias, atendimento dos programas de saúde pública.

A emergência dos assentamentos rurais no cenário da questão
agrária brasileira é um dos fatos marcantes que caracterizam
especialmente o período que vai da década de 1980 até os dias
atuais. Com os assentamentos, ganham projeção também os
seus sujeitos diretos, isto é, os assentados rurais, bem como os
movimentos e as organizações que, em boa parte dos casos,
garantiram o apoio necessário para que o esforço despendido
ao longo de lutas das mais diversas resultasse na constituição
de projetos de Reforma Agrária, também conhecidos como
assentamentos rurais. Assim, em diferentes situações, número
expressivo de trabalhadores que participaram de processos de
ocupação de terra deixaram de ser acampados para se
tornarem, num momento seguinte, assentados. (LEITE, 2012, p.
110).

Essas conquistas sociais possibilitaram o fortalecimento do enraizamento das famílias no território camponês com dignidade.

\section{Inventário: ressignificação da identidade da escola do campo}

A Escola Classe Sonhém de Cima atende as famílias do Assentamento e das demais comunidades camponesas e urbanas circunvizinhas há quase duas décadas, com o ensino da Educação Infantil até o $5^{\circ}$ ano dos Anos Iniciais do Ensino Fundamental. 
As escolas do campo do Distrito Federal, seguindo as orientações dos Pressupostos do Currículo em Movimento (SEEDF, 2014) e a Portaria $\mathrm{n}^{\circ}$ 419/2018 da Secretaria de Estado de Educação do Distrito Federal, que rege a Política de Educação Básica do Campo, em seu artigo $4^{\circ}$ institui:

O Inventário Social, Histórico e Cultural como instrumento basilar na construção da identitária da Escola do Campo, tendo como fundamento os processos sociais estabelecidos no território, os saberes próprios dos estudantes, como sujeitos do campo, a memória coletiva, os conhecimentos historicamente estabelecidos pela sociedade e pelos movimentos sociais. (DODF, 2018, p. 2).

Os educadores e as educadores da Sonhém reconheceram a necessidade de aprofundar e apreender os princípios e elementos constitutivos da Educação do Campo para a construção da identidade da escola do campo, como agência social educativa e formativa no território camponês, através da incorporação dos saberes e fazeres das populações camponesas nas práxis pedagógicas, como um caminho a ser percorrido para a transformação da escola do campo.

A identidade da escola do campo é definida pela sua vinculação às questões inerentes à sua realidade, ancorando-se na temporalidade e saberes próprios dos estudantes, na memória coletiva que sinaliza futuros, na rede de ciência e tecnologia disponível na sociedade e nos movimentos sociais em defesa de projetos que associem as soluções exigidas por essas questões à qualidade social da vida coletiva do país. (Diretrizes Operacionais para a Educação Básica nas Escolas do Campo, 2002).

Essa aproximação da escola com o meio social (o território educativo), com suas especificidades e suas contradições sociais, no qual está inserida a escola, apontou a possibilidade de desenvolver os princípios formativos: estudo da realidade, a auto-organização dos estudantes e o trabalho coletivo. Esses elementos pedagógicos foram trabalhados nas escolas comunas, no período da Revolução Russa nos anos de 1917 a 1931, apresentados nos referenciais teóricos Freitas (2010; 2011); Krupskaya (2017); Pistrak (2011; 2013); e (SHULGIN, 2013). Aqui no Brasil, as experiências da pedagogia socialista estão sendo desenvolvidas nas escolas itinerantes do Movimento dos Trabalhadores Sem Terra (MST) através das referências de Sapelli (2019). 
Nessa etapa da construção do inventário social, histórico, cultural e ambiental da escola do campo, os educadores e as educadoras definiram as ações investigativas da realidade, para identificar as fontes educativas e as agências formativas existentes no território educativo, com a intencionalidade de reconhecer os sujeitos que compõem o território camponês e os seus modos de produção de vida. E decidiram seguir a proposta do inventário das fontes educativas do meio educativo, como propõe Freitas (2010):

Inventário das fontes educativas do meio educativo em geral: naturais, históricas, sociais e culturais, incluindo-se outras agencias formativas existentes (cooperativas, associações, entre outras). Aqui se trata de identificar os elementos existentes na vida que podem apoiar os processos educativos previstos. Meios naturais: geográficos (rios, montanhas), fauna, flora, etc. Meios sociais: formas de sobrevivência e produção da vida, bem como formas de organização local. Históricas: marcas históricas deixadas na região, pessoas que detêm a memória do local ou da região, fontes históricas objetivas existentes, entre outras. Meio cultural: como danças, músicas, contos, tradições locais ou regionais, saberes, entre outros. Esse levantamento é importante para que se possa caracterizar o meio educativo em geral, a vida local e regional. (Freitas, 2010, p.14).

Os educadores e as educadoras cientes da importância do Inventário Escola Classe Sonhém de Cima: os saberes e os fazeres do campo com prosa e rimas como elemento investigativo e forjador da identidade da escola na perspectiva da Educação do Campo, para aproximar e interagir com os sujeitos históricos da população camponesa, para conhecer a história de luta, resistência, persistência e conquista da terra e consequentemente reconhecer a cultura camponesa do Assentamento Contagem. Como Tardin (2012) ressalta que o camponês é um sujeito de conhecimentos amplos.

Impõe-se ao camponês a exigência de conhecimentos amplos, entre outros, sobre as plantas cultivadas e os animais silvestres criados; saberes sobre reprodução, produção, proteção, conservação, transformação e armazenagem; sobre usos que incluem a gastronomia, a terapêutica e a transformação doméstica; sobre os solos e a água - seus manejos e conservação, que implicam obras e equipamentos variados; sobre o clima - vento, temperatura, chuva, seca, geada; sobre as estações do ano e o ciclo lunar; sobre fertilizantes, ferramentas e máquinas de trabalho; sobre construção; e sobre produção artesanal - roupas, calçados, adornos...(TARDIN, 2012, p. 182). 


\section{Iniciando a prosa com a população camponesa}

Desde 2017, os educadores e as educadoras promovem e mediam práticas pedagógicas com os educandos e as educandas com a intencionalidade de materializar a aproximação e a interação dos saberes, dos fazeres e dos valores da população camponesa com os conteúdos curriculares trabalhados no cotidiano escolar e, ao mesmo tempo, materializar a construção do inventário social, histórico e cultural e ambiental, intitulado Escola Classe Sonhém de Cima: os fazeres e os saberes do campo com prosa e rima.

Essa aproximação dos conhecimentos científicos com os saberes e os fazeres da população camponesa, materializa a segunda tarefa formativa da escola, defendida por Krupskaya (2017):

A segunda tarefa formativa da escola de primeiro grau é ensinar
a criança nos livros, na ciência, a buscar respostas para as
questões que aparecem, dar a ela a consciência de que pode
procurar nos livros o que pensou a humanidade nesta ou
naquela questão. Disso decorre a necessidade de dar grande
lugar na escola, mesmo no primeiro grau, ao estudo
independente das crianças, mudando o caráter dos estudos
escolares, ampliando a seleção de materiais para estudo.
(Krupskaya, 2017, p.105-6).

As estratégias desenvolvidas foram as seguintes: a) visita às famílias camponesas e aos locais de trabalho; b) entrevistas e roda de conversas com as famílias camponesas; c) registro de fotos e vídeos dos sujeitos e da realidade encontrada; d) produção de textos (memórias, poesias e contos) e de desenhos pelos estudantes; e) apresentação de encenação teatral, mística e sarau poético; f) análise dos dados gerados e exposição dos trabalhos para a comunidade escolar.

\section{A banana, elemento investigativo da realidade}

As duas primeiras ações investigativas aconteceram no último bimestre do ano letivo de 2017, foram a entrevista com a agricultora assentada Dona Roseli, no pátio da escola, com a participação de todas as turmas e a visita a lavoura de bananas da família. Foram momentos significativos para valorizar a luta e a resistência da família camponesa em conquistar a terra e conhecer o cultivo de bananas, que está sendo uma fonte econômica importante para os agricultores do Assentamento Contagem. 
Uma das famílias que participaram do processo de ocupação, foi o casal Seu Caetano Gomes Neto e Dona Maria Roseli de Freitas e seus seis filhos. Oriundos de Caririaçu do Estado do Ceará, chegaram no Distrito Federal no final da década de 1980. Trabalharam como chacareiros na zona rural de Planaltina DF. Depois decidiram sair em busca da terra própria, começaram a participar de um movimento de Sem Terra e ficaram acampados à beira da rodovia na região do Pipiripau-DF.

Ao saberem da existência das condições ilegais da Fazenda Maranhão, o grupo de mais de 40 famílias decidiram iniciar o processo de ocupação das terras devolutas da Fazenda Maranhão. Dois filhos do casal, Damiana Michelly de Freitas Gomes e Wellington de Freitas Gomes, na época duas crianças, respectivamente com 12 e 7 anos, relataram como foi esse momento.

Atualmente trabalham na escola do Assentamento. Ela professora e ele, funcionário de apoio. Contaram como foi o momento que chegaram na fazenda devoluta. Michelly, respondeu as seguintes perguntas: Você lembra o dia que chegaram no galpão da fazenda? No acampamento era organizado como? Eram quantas famílias? E ficaram quanto tempo no acampamento? As dificuldades? O que aprendeu sobre a importância da terra para os Sem Terra?

Chegamos em 1994. Na época eu tinha 12 anos, Wellington tinha 6. Ficamos no barracão eram 35 famílias. Ficamos uns três meses, não foi muito tempo que ficamos acampados no barracão, não. No barracão, as 35 famílias viviam todas juntas, o espaço de cada família era dividido por lona. A gente comia todo mundo junto. Tentando um ajudar o outro. Não tinha banheiro, tudo muito precário. Depois o pessoal começou a andar fazendo a divisão das terras. Cada um escolheu o seu lote e foi saindo do barracão. A terra é importante porque foi através da luta, tivemos a conquista da terra, um local para trabalhar e poder sustentar a família. A terra é um símbolo de vida, pois com a terra cada um foi trabalhando, sustentando sua família, construindo sua moradia e vivendo. (Depoimento de Michelly).

Essa ação pedagógica exitosa demonstrou, a todos os envolvidos, a importância da interação da escola com a população camponesa. Possibilitou aos envolvidos na pesquisa, através dos depoimentos, sensibilizar-se com as histórias e ao mesmo tempo, valorizar e respeitar os sujeitos históricos que moram e trabalham no território camponês. 


\section{A prosa com outros agentes formativos}

Em 2018, os educadores e as educadoras da escola permearam nos princípios constitutivos e as matrizes formativas da Educação do Campo nos momentos de coordenação pedagógica, para discutir, planejar e decidir as ações pedagógicas do Inventário.

Umas das ações foi a roda de conversa com os representantes das agências formativas presentes no Assentamento, que são as três associações comunitárias - Associação dos Produtores Rurais do Contagem (APROCON), a primeira e responsável pela organização política do processo de transição do acampamento para assentamento; Associação do Grupo de Mulheres Produtoras do Assentamento Contagem, conhecidas como Flores do Contagem, trabalham na produção e comercializam de produtos de panificação (pães e bolos); e Associação dos Produtores de Banana. Essa prosa foi importante para reconhecer a importância do associativismo e do cooperativismo para unir e o fortalecer as camponesas e os camponeses contra as investidas agressivas do capital.

\section{Caminho do mel: da sala até a casa dos avós de Samuel}

No dia 19 de outubro de 2018, um dos estudantes da turma do quarto ano dos Anos Iniciais do Ensino Fundamental, estava tossindo muito na sala de aula. O professor pergunta se o mesmo está tomando remédio e orienta que o chá de limão com mel é bom para aliviar a tosse.

No início da outra semana, dia 22, a turma foi surpreendida pela atitude solidária de um dos estudantes. Samuel trouxe uma vasilha cheia de favos de mel de abelha e entregou para o estudante que estava tossindo no último dia de aula. O professor pediu a vasilha para o estudante, a turma sentou em círculo e iniciou-se a aula sobre a produção de mel das abelhas. Ele fez perguntas provocadoras para os educandos apresentar os conhecimentos prévios sobre $o$ doce conteúdo. Em seguida, os educandos tiveram oportunidade de pegar e visualizar o formato hexagonal dos favos de mel.

Foi trabalhado o texto Loucos por Flores no livro de Língua Portuguesa da Coleção Girassol, para aprender a importância dos animais polinizadores, em especial, as abelhas. Experimentaram o sabor do mel natural. $O$ educando que 
trouxe o mel, informou que seu avô é apicultor. E professor pediu para ele explicar para a turma qual é o trabalho de um apicultor. A turma ficou interessada em aprender os conhecimentos sobre a abelha e a produção de mel. O professor aproveitou a oportunidade para motivar a pesquisa e aprofundar os estudos sobre o tema, mandou um recado para a mãe do estudante Samuel, para acertar a visita da turma e ter uma prosa com os seus avós e aprender mais sobre o doce conteúdo. O convite foi aceito.

No dia 28 de outubro, foi o dia marcado para conhecer os avós do estudante Samuel. A turma junto com seu professor foi a pé, conhecendo o assentamento Contagem. Passaram sobre a ponte do Rio Contagem e chegaram na chácara 13. Encontraram Seu Saturnino na roça, capinando na lavoura de milho e feijão de corda. Prosaram com avô de Samuel no meio da roça mesmo. O professor foi mediando a prosa e os educandos e as educandas perguntando, anotando as respostas e aprendendo sobre os saberes e os fazeres do campo. Depois da prosa inicial, foram convidados por Seu Saturnino para ir na casa dele e conhecer a sua esposa, Dona Vitalina. A prosa investigativa continuou, a aprendizagem prosseguiu.

A turma conheceu a história do casal - Seu Saturnino e Dona Vitalina. Oriundos da região do Nordeste, antes de serem assentados da Reforma Agrária, tentaram a sorte em outras terras, mas sem abandonar o sonho de ter o seu pedaço de chão.

Seu Saturnino Gomes Vitor, com seus 86 anos de vida, contou sua história, desde a sua vinda do estado da Paraíba, região do Nordeste até chegar no Assentamento Contagem. Em 1943, o avô dos educandos, ainda criança veio com seus parentes num caminhão improvisado, chamado pau-de-arara. Foi trabalhar numa fazenda em Goianésia, estado de Goiás.

Dona Vitalina Maria Vitor, 81 anos de idade, contou-nos que nasceu na Bahia e que conheceu o esposo dela numa fazenda no Estado de Goiás.

Em seguida, Seu Saturnino (homem bom de prosa) contou aos presentes que chegou em Brasília, em 1958, ainda bem no início da construção da capital do Brasil. Foi engraxate e depois sua profissão foi marceneiro na construção de Brasília, inaugurada em 21 de abril de 1960. Os operários da construção de Brasília vieram de todas regiões do Brasil, são chamados de candangos. 
Nosso candango ilustre explicou como as abelhas produzem o mel e nos ofereceu o produto do trabalho das dedicadas miudinhas operárias. Saboreamos mel de abelha in natura. A nossa aula foi muito bacana, como uma educanda afirmou: "Foi massa!"

\section{Caminho da escola: conhecendo a realidade}

No primeiro semestre do ano letivo de 2019, os educadores e as educadoras da escola (equipe gestora, docentes, funcionários de apoio, monitores e motoristas dos ônibus escolares) desenvolveram a ação pedagógica - Os caminhos da escola: os sujeitos e os modos de produção do território camponês - com o intuito de reconhecer o trajeto que os educandos, que moram no Assentamento Contagem e nas fazendas circunvizinhas, percorrem para chegar à escola.

Com a orientação do motorista do ônibus escolar, as educadoras e os educadores conheceram as residências dos educandos nas chácaras do Assentamento e nas fazendas e também as dificuldades enfrentadas pelo grupo (motorista, monitor e educandos) no decorrer do trajeto: os buracos na estrada e as pontes em estado precário de uso que dificultam o tráfego do ônibus, principalmente no período de chuvas.

Aproveitaram para observar o espaço geográfico e os recursos naturais do território camponês, que está inserido na APA do Planalto Central, reserva do Bioma Cerrado e banhado pelo Rio Maranhão e demais afluentes.

Nessa mesma ação, os educadores e as educadoras visitaram a Fazenda Roda d'água, para conhecer o prédio escolar desativado da Escola Sonhém de Baixo (estrutura física de uma única sala de aula, uma cantina e um banheiro) incrustada na lavoura de mangas. Essa unidade de ensino atendia os estudantes da região antes da chegada das famílias na Fazenda Maranhão.

Como foi lembrado pela merendeira, não tinha ônibus escolar, para estudar ela ia estudar caminhando da casa dela, numa das fazendas da região, até a escola. Era muito longe e cansativo para todos. As crianças acampadas não estudaram na escola antiga.

O término do dia educativo foi na fazenda, onde a família da comunidade escolar ofereceu um cardápio repleto de sabores da tradição camponesa. 


\title{
Caminho da escola: sujeitos e modos de produção
}

No dia 30 de abril, o Coletivo Girassol (turmas do $5^{\circ}$ Ano) junto com a gestora da escola e três educadores visitaram núcleos familiares, no ônibus escolar que percorre o assentamento e as fazendas, para prosar e conhecer a história dos posseiros e dos Sem Terra, suas lutas, conquistas dos direitos sociais e os modos de produção.

Esse processo formativo investigativo se faz necessário, para aproximar os estudantes e os educadores da realidade do meio no qual está inserido, como defende a pedagoga socialista Krupskaya (2017), ao indicar as tarefas da escola do primeiro grau:

\begin{abstract}
Antes de tudo, a escola deve despertar na criança a curiosidade, um interesse ativo pelo ambiente, um interesse investigativo pelos fenômenos e fatos, tanto no campo das ciências naturais como da vida social. Para isso, é necessária uma forte ligação da escola com a população, com seu trabalho, com toda sua vida econômica; no ensino é necessário apoiar-se na realidade do meio ambiente da criança. É necessário um método investigativo de abordagem das disciplinas estudadas, que por sua vez coloque em primeiro lugar as ciências naturais e o trabalho. (Krupskaya, 2017, p. 105).
\end{abstract}

Os momentos de prosas com os moradores, nas chácaras de algumas famílias e na padaria da Associação do Grupo de Mulheres Produtoras do Assentamento Contagem, conhecidas como Flores do Contagem, possibilitou aos educandos e educadores conhecer a história dos homens e mulheres camponesas, as formas de trabalho, os modos de produção de alimentos e a criação de animais, também para compreender o sentimento de pertencimento à terra e a importância do trabalho como elementos constituintes da identidade da população camponesa.

\section{Visita ao galpão: onde tudo começou}

A visita ao galpão desativado da sede da fazenda, que serviu de acampamento para as famílias dos Sem Terra deixou as educandas e os educandos curiosos para saber como foi a chegada das famílias para acampar no curral. Teve a mediação de Wellington, filho do casal Seu Caetano e Dona Roseli, funcionário da escola, que na época era uma criança de 7 anos. 
Wellington confirmou o que foi relatado pelos primeiros moradores: era um dia chuvoso, a estrada estreita de difícil acesso, os caminhões atolaram. Tiveram o apoio do vaqueiro da fazenda, Seu Nelson e família. O local improvisado e escolhido para ser o acampamento tinha muito mato. Lembrou que na primeira noite encontraram muitas cobras. As famílias acampadas organizaram o galpão e demarcaram o espaço de cada família com lonas pretas. A cozinha coletiva com a organização dos acampados é outra lembrança do guia da atividade. A água para o consumo das famílias era buscada no Rio Contagem, distante uns 300 metros do acampamento.

\section{As Flores e os sabores do Contagem}

Seguindo o roteiro, o Coletivo Girassol e os educadores foram à sede da Associação de Mulheres, as Flores do Contagem, para conhecer a história e a luta das mulheres assentadas que trabalham coletivamente na produção de produtos de panificação (pães e bolos). A visita foi marcada previamente através do contato com a presidente da Flores do Contagem, a senhora Maria das Dores Moraes Silva, que ficou muito feliz em receber a equipe da escola no espaço de trabalho das mulheres.

A mãe de um dos estudantes do Coletivo Girassol, Dona Enilda Emílio Ferreira, foi a anfitriã. Ela mostrou as dependências da padaria e informou que a Associação das Mulheres foi fundada no dia 21 de abril de 1994. Contou sobre o trabalho coletivo das mulheres, desde aquisição das matérias-primas (plantadas e colhidas no próprio assentamento: abóbora, banana, batata doce e mandioca) que são utilizadas na produção dos pães e bolos até a venda dos produtos. Foi um momento rico, pois os presentes reconheceram a importância do trabalho para o empoderamento das mulheres no contexto social campesino. No final, os presentes apreciaram e degustaram os sabores das guloseimas produzidas pelas mulheres, as Flores do Contagem.

\section{O posseiro plantou arroz e o sonho de ter a terra}

Depois, no mesmo dia, o grupo de pesquisadores e pesquisadoras foram conhecer e prosar com o casal Seu Alaciel e Dona Fátima. Os primeiros posseiros da Fazenda Maranhão. A turma foi recepcionada na varanda da casa 
da propriedade com muita prosa e muitos bolos, para acalentar mais ainda o processo investigativo da cultura camponesa.

Seu Alaciel, homem bom de prosa, contou que veio da comunidade vizinha, Córrego de Ouro. Conhecedor da região e da situação das terras que "não tinha dono", plantou arroz e começou a criar vacas e bois nas margens do Rio Maranhão. Com o passar do tempo, junto com outros posseiros, decide lutar para ficar em definitivo no pedaço de chão.

No início de 1994, em visita ao escritório do Instituto Nacional de Colonização e Reforma Agrária (Incra), em Goiânia - GO, conheceram os representantes dos Sem Terra. Relataram sobre a situação da fazenda da região do Rio Maranhão e aproveitaram as políticas públicas de Reforma Agrária vigentes para concretizar o processo de ocupação das terras devolutas.

Atualmente, o casal trabalha em seu lote com a pecuária, em especial na criação do gado bovino e suíno.

Um momento que os estudantes ficaram mais empolgados foi quando Seu Alaciel liberou a pescaria nos tanques de peixes. O Coletivo Girassol aprendeu sobre a diversidade de produção de vida existente no território camponês.

\section{A mandioca, mais que um alimento}

O passeio na comunidade camponesa, nesse dia, finalizou na chácara de Dona Luzia, assentada, avó de dois educandos do Coletivo Girassol. Dona Luzia, e seus familiares fizeram parte do grupo dos Sem Terra, que acamparam no galpão da fazenda.

Nessa propriedade, o trabalho familiar é centralizado no cultivo da mandioca. O Coletivo Girassol e os educadores acompanharam as etapas da produção de farinha. Aprenderam sobre o ciclo da mandioca (desde do plantio até a produção da farinha e outros derivados) com a contribuição de um dos trabalhadores e, também, dos camponeses mirins (integrantes do Coletivo Girassol) que foram os guias dentro do espaço de beneficiamento da mandioca. Os presentes foram informados que os produtos são comercializados em feiras e mercados do Distrito Federal.

Ao voltar à escola, os integrantes do Coletivo Girassol participaram de uma roda de conversa com a mediação dos educadores para avaliar o dia de 
aprendizagem. Demonstraram nos depoimentos que aprenderam sobre as diversas formas de trabalho presenciadas no percurso formativo e sentiram-se privilegiados em conhecer a história e a luta das mulheres e dos homens para conquistar a terra, como um direito social, para morar e trabalhar na produção de alimentos e sustentar as famílias com dignidade. Os educandos e as educandas que são herdeiros dos Sem Terra declararam que não sentem vergonha da história dos pais e dos avôs, aliás são orgulhosos de serem camponeses.

\title{
A contagem do Contagem
}

Uma das ações do projeto Escola Classe Sonhém de Cima: saberes e fazeres do campo com prosas e rimas, foi o espetáculo teatral "A contagem do Contagem". Tiveram dois momentos, no biênio 2018-19, A primeira apresentação aconteceu no Teatro de Sobradinho e a segunda, no Assentamento Contagem. Foram desenvolvidas atividades na perspectiva do trabalho coletivo. Krupskaya (2017) ressalta a importância da inserção do trabalho nas ações pedagógicas, sendo uma das três tarefas da escola do primeiro grau:

\begin{abstract}
A terceira e não menos importante tarefa é desenvolver nas crianças o hábito de viver, estudar e trabalhar coletivamente. Isto define a natureza da organização da vida escolar, a autoorganização das crianças, a ajuda mútua das crianças e outras. Disso decorre o método do trabalho: crítica coletiva do ver e ouvir, hábito de alcançar determinados objetivos pela união de forças e a divisão de trabalho de acordo com as forças e possibilidades; também disso decorre a natureza do trabalho da escola e a natureza do trabalho escolar, isto é, o trabalho coletivo, a organização criativa, a necessidade de conceder amplo lugar à arte, arte que é próxima, que provoca a emoção coletiva, que desenvolve predisposições sociais. (Krupskaya, 2017, p.106).
\end{abstract}

Em 2018, a turma do $4^{\circ}$ ano, denominada Coletivo Girassol, ensaia e apresenta A contagem do Contagem, no Teatro de Sobradinho - DF, no projeto Sonhém Conta Histórias, onde as turmas da escola escolhem uma história da literatura infantil para encenar teatralmente para todas as turmas, as famílias e demais convidados. 
O Coletivo Girassol decidiu contar a história das famílias do Assentamento Contagem, em prosa e em versos, com música e pamonha para comemorar a luta e a conquista da terra da população camponesa.

\section{A história volta à origem}

Nos meses de abril e maio de 2019 , os dois educadores das turmas do $5^{\circ}$ ano, mediaram as ações pedagógicas com o Coletivo Girassol, com a intencionalidade principal de organizar e apresentar a encenação teatral $A$ contagem do Contagem, para a plateia especial: as famílias assentadas do Assentamento.

O local escolhido tem um significado histórico crucial para a população camponesa, o galpão da fazenda, onde as famílias escolheram para ser o acampamento, quando iniciou o processo de ocupação da fazenda.

\section{Terra, direito, trabalho e alimento viram mística}

No dia 13 de abril, os trinta nove estudantes das duas turmas dos $5^{\circ}$ Anos foram divididos em quatro grupos, a partir dos eixos norteadores Terra, Direito, Trabalho e Alimentos. Participaram do debate sobre a importância dos eixos norteadores, com o intuito de conhecer os mesmos e planejar coletivamente a encenação teatral na perspectiva da mística dos movimentos sociais.

Para Bogo (2012), os movimentos populares compreendem a mística como expressões da cultura, da arte e dos valores como parte constitutiva da experiência edificada na luta pela transformação da realidade social, indo em direção ao topos, a parte realizável da utopia.

A mística é o ânimo para enfrentar as dificuldades e sustentar a solidariedade entre aqueles que lutam. A mística não somente ajuda a transformar os ambientes e cenários sociais; acima de tudo, impulsiona e provoca mudanças por fora e por dentro dos sujeitos, tal qual o fazem as frutas, que, ao crescerem, ganham a massa que lhes dá volume e, ao mesmo tempo, por dentro, abrigam a formação das sementes. (BOGO, 2012, p. 478).

A primeira ação pedagógica foi trabalhar a releitura de uma das fotos do livro Terra de Sebastião Salgado. Um olhar crítico para observar as pessoas fotografadas e ressignificar a imagem com o trabalho de recortar e recriar novas fotos. Foi trabalhado a música Assentamento de Chico Buarque para analisar a 
constituição do assentamento na percepção do autor e relacionando com a história da população camponesa do Assentamento Contagem.

Outra ação pedagógica foi a leitura dos poemas $O$ Cântico da Terra e Canção da Terra, respectivamente de Cora Coralina e Pedro Munhoz, para o Coletivo Girassol identificar os elementos Terra, Direito, Trabalho e Alimento nos textos e compreender a importância dos mesmos para a população camponesa.

Cada grupo ficou com a responsabilidade de construir o estandarte representativo dos elementos trabalhados e também a produção de para cartazes de divulgação da encenação teatral.

Outro elemento artístico que foi trabalhado pelo Coletivo Girassol para ser inserido na encenação teatral foi a perna de pau. Os estudantes da escola frequentam a oficina de psicomotricidade Gigantes da Sonhém, com a orientação dos professores que desenvolvem as habilidades dos estudantes para andar com pernas de pau. Para a apresentação da $A$ contagem do Contagem, o estandarte representativo dos eixos centrais - Terra, Direito, Trabalho e Alimento - foram carregados e expostos por um estudante com pernas de pau.

Entre os dias 06 a 17 de maio, o Coletivo Girassol dedicou-se para os preparativos da apresentação teatral: os ensaios; a definição e organização dos figurinos das personagens; a produção dos estandartes; o desenho e a confecção dos cartazes-convite; a entrega dos cartazes-convite; os treinos com as pernas de pau, para definir os estudantes que seriam os abre-alas; a escolha dos produtos agrícolas para compor o nome Contagem no início da encenação teatral e outros trabalhos.

Na semana anterior a apresentação, a equipe da Administração da Fercal contribuiu com a capina e a limpeza do galpão nas áreas interna e externa, onde aconteceu a apresentação teatral. Outra parceria, foi com a igreja católica, o representante dessa agência formativa, ofereceu os bancos para a plateia sentar.

\section{A plateia é protagonista da história de luta}

No dia 20 de maio, à tarde, foi o dia da apresentação teatral, $A$ contagem do Contagem, no local onde foi escolhido para ser o acampamento das famílias 
acampadas. Depois de 25 anos, as mulheres e os homens camponeses foram plateia para assistir a própria história. São protagonistas e exemplos de luta, de resistência e resiliência coletiva para conquistar a terra.

O Coletivo Girassol chegou com uma hora de antecedência para os preparativos, como vestir os figurinos e ouvir as orientações sobre a apresentação. Tiveram o apoio de duas famílias camponesas que ofereceram as casas para servir de camarim. As mulheres e os homens protagonistas da história do Assentamento Contagem e os demais convidados foram chegando aos poucos. Tudo pronto.

O espetáculo foi dividido em três atos. O início teve a leitura dos trechos do Cântico da Terra de Cora Coralina. Em seguida, ao som da música Cio da Terra nas vozes de Pena Branca e Xavantinho, os quatro grupos adentram no cenário (área externa do galpão). Na frente de cada fila indiana, o abre-ala na perna de pau com o estandarte de cada elemento - Terra, Direito, Trabalho e Alimento. Atrás, as personagens da história, as famílias camponesas.

Quando chegaram no centro do terreiro, construíram o nome Contagem com os produtos agrícolas. Cantaram a introdução da música Disparada de Geraldo Vandré e Théo de Barros: "preparem seu coração, pra coisas que vou contar, eu venho lá do sertão, eu venho lá do sertão, o posso não lhe agradar..."

Os dois narradores, dois filhos de assentados começaram a narrar $A$ contagem do Contagem - a história das quatro dezenas de famílias camponesas que ocuparam a fazenda Maranhão, nos meados da década de 1990, que mesmo com todas adversidades e dificuldades não desistiram do sonho de ter o pedaço de chão, para morar, cultivar a terra, colher os alimentos e sustentar a família através do trabalho com dignidade e orgulho de ser camponês.

No final do segundo ato, as personagens foram trocar os figurinos para voltarem vestidos para a festa da pamonha. Nesse intervalo, o professor convidou as mulheres e os homens assentados, os protagonistas reais, para um momento de prosa, para os outros convidados conhecê-los, ouvi-los e receber os aplausos pela linda história de luta e conquista da terra.

E a contagem do Contagem terminou com muita festa e alegria. O Coletivo Girassol dançou, distribuiu pamonha e bolo de milho, convidou a plateia para festejar a história da população camponesa do Assentamento Contagem. 
A contagem do Contagem trouxe à tona as lembranças, as memórias na fala e no olhar da mulher e do homem do campo, o brilho e o encantamento da luta e da resistência, mesmo com os percalços do ambiente desconhecido e inóspito, o sonho de conquistar a terra tão sonhada falou mais alto.

\section{Considerações finais}

O trabalho investigativo realizado pelos educadores e educandos da escola do campo, a partir da prática pedagógica do projeto Escola Classe Sonhém de Cima: os saberes e os fazeres do campo com prosas e rimas possibilitou conhecer o território camponês e os sujeitos históricos e os modos de produção de vida.

Os momentos de aproximação e interação da escola com a comunidade camponesa possibilitaram aos educandos e educadores conhecer história e a cultura como elementos indissociáveis para a identidade da população do Assentamento Contagem. Para os sujeitos históricos camponeses foi importante reconhecer a escola como uma agência formativa parceira, que se faz presente no território.

Nesse período de três anos, as ações pedagógicas coletivas, dialéticas, dialógicas, interdisciplinares e práxicas desenvolvidas na Escola Classe Sonhém de Cima, com o intuito de materializar a construção do inventário da realidade do meio, foram exitosas. Conhecer as matrizes formativas, as fontes educativas, as formas de trabalho e as interações sociais dos sujeitos históricos presentes no território camponês e fomentar a ressignificação dos conteúdos curriculares em consonância com os saberes e os fazeres da população camponesa, são elos imprescindíveis do movimento de constituição da identidade da escola na perspectiva dos princípios da Educação do Campo.

\section{Referências}

BOGO, A. Mística. In: CALDART, Roseli et al. (Org.) Dicionário da educação do campo. Rio de Janeiro/São Paulo: Escola Politécnica de Saúde Joaquim Venâncio/Expressão Popular, 2012. p. 475-79.

BRASIL. Ministério da Educação. Conselho Nacional de Educação. Parecer CNE/CBE n. 36/2001. Diretrizes operacionais para a educação básica nas escolas do campo. Brasília: MEC/CNE, 2002. 
DISTRITO FEDERAL. Secretaria de Estado de Educação do Distrito Federal SEEDF. Portaria 419, de 21 de dezembro de 2018. Brasília: SEEDF, 2018.

Currículo em Movimento da Educação Básica da Secretaria de Estado de Educação do Distrito Federal. Secretaria de Estado de Educação do Distrito Federal. Brasília, SEEDF, 2018.

SEEDF. O Inventário Social, Histórico e Cultural: uma proposta pedagógica de integração curricular para as unidades escolares do campo da SEEDF. Brasília, SEEDF, 2016.

SEEDF. Diretrizes Pedagógicas da Educação Básica do Campo para a Rede Pública de Ensino do Distrito Federal. SEEDF, Brasília, 2019.

FERNANDES, B. M. Acampamento. In: CALDART, Roseli et al. (Org.) Dicionário da educação do campo. Rio de Janeiro/São Paulo: Escola Politécnica de Saúde Joaquim Venâncio/Expressão Popular, 2012. p. 21-7.

Território Camponês. In: CALDART, Roseli et al. (Org.) Dicionário da educação do campo. Rio de Janeiro/São Paulo: Escola Politécnica de Saúde Joaquim Venâncio/Expressão Popular, 2012. p. 746-49.

FREITAS, Luiz Carlos. A escola única do trabalho. Cadernos do ITERRA n. 15 , set/2010.

Krupskaya. N, K. A construção da pedagogia socialista: escritos selecionados. São Paulo: Expressão Popular, 2017.

LEITE, S. P. Assentamento Rural. In: CALDART, Roseli et al. (Org.) Dicionário da educação do campo. Rio de Janeiro/São Paulo: Escola Politécnica de Saúde Joaquim Venâncio/Expressão Popular, 2012. p. 110-13.

Pistrak, Moysey Mikhailovich (org.). Escola Comuna. $2^{a}$ ed.. Tradução de Luiz Carlos Freitas e Alexandra Marenich. São Paulo. Expressão Popular, 2013.

Fundamentos da escola do trabalho. Tradução de Luiz Carlos de Freitas. São Paulo: Expressão Popular, 2018.

SHULGIN, Viktor, N. Rumo ao politecnismo (artigos e conferências). Tradução de Alexein Lazarev e Luiz Carlos de Freitas. São Paulo: Editora Expresão Popular, 2013.

SAPELLI, Marlene Lúcia Siebert. Ensaios da escola do trabalho na luta pela terra: 15 anos da escola itinerante no Paraná. Marlene Lúcia Siebert Sapelli, Valter de Jesus Leite, Caroline Bahniuk. São Paulo: Expressão Popular, 2019.

TARDIN, J. M. Cultura Camponesa. In: CALDART, Roseli et al. (Org.) Dicionário da educação do campo. Rio de Janeiro/São Paulo: Escola Politécnica de Saúde Joaquim Venâncio/Expressão Popular, 2012. p. 180-88. 
Sobre o autor

Sérgio LuizTeixeira

sergioseduc@gmail.com

Mestre em Educação do Campo pela UnB; Especialista em Gestao Escolar (UnB), Especialista em Coordenação Pedagogica (UnB), Pedagogo UNEB; Professor de Escola do Campo da Secretaria de Estado de Educação do Distrito Federal; Integrante do Fórum de Educação do Campo do Distrito Federal. 